\title{
Tools, minds and machines : an excursion in the philosophy of technology
}

\section{Tim Ingold}

\section{Q OpenEdition \\ 1 Journals}

\section{Electronic version}

URL: https://journals.openedition.org/tc/805

DOI: $10.4000 /$ tc. 805

ISSN: $1952-420 X$

\section{Publisher}

Éditions de l'EHESS

\section{Printed version}

Date of publication: 1 June 1989

ISSN: 0248-6016

\section{Electronic reference}

Tim Ingold, "Tools, minds and machines : an excursion in the philosophy of technology", Techniques \& Culture [Online], 12 | 1989, Online since 16 January 2006, connection on 29 September 2022. URL: http://journals.openedition.org/tc/805 ; DOI: https://doi.org/10.4000/tc.805

This text was automatically generated on 29 September 2022.

All rights reserved 


\section{Tools, minds and machines : an excursion in the philosophy of technology}

Tim Ingold 